\title{
How Students of Preschool Education Perceive Their Play Competences - An Analysis of Their Involvement in Children's Play
}

SANJA TATAlOVić VORKAPIĆ ${ }^{* 1}$ AND VESNA KatiĆ ${ }^{2}$

$\propto$ Preschool teachers play a very important but highly sensitive role in preschool children's play. It is therefore very important to build their play competences in a quality way. As this is not easily achieved, the main objective of the present study was to analyse the roles of students of preschool education in children's play. The study included 36 students enrolled at the Faculty of Teacher Education in Rijeka, Croatia. Through a qualitative analysis of the students' preparations for their practice, it was determined that the majority of students use didactic play and play with rules with children. Although the students demonstrated the expected role in children's play, which positively influenced the educational work and the overall well-being of the children, some of the students were not decisive. Thus, the question arises as to how to improve the acquisition of play competences in students of preschool education.

Keywords: roles, students of preschool education, play competences

$1 \quad{ }^{*}$ Corresponding Author. Faculty of Teacher Education, University of Rijeka, Rijeka, Croatia; sanjatv@ufri.hr

2 Faculty of Teacher Education, University of Rijeka, Rijeka, Croatia 


\section{Kako študentje predšolske vzgoje zaznavajo svoje kompetence za igro - analiza njihove vključenosti v otroško igro}

Seyyed Hatam Tamimi SA'D ${ }^{*}$ in Zohre Qadermazi

$\propto$ Predšolski vzgojitelji imajo pomembno in zelo občutljivo vlogo pri igri predšolskih otrok, zato je pomembno, da si pridobijo kompetence za igro na kakovosten način. Ker to ni lahko doseči, je bil glavni namen predstavljene raziskave analizirati vlogo študentov predšolske vzgoje pri otrokovi igri. V raziskavo je bilo vključenih 36 študentov Pedagoške fakultete na Reki na Hrvaškem. S kvalitativno analizo priprav študentov na prakso je bilo ugotovljeno, da večina študentov pri delu $\mathrm{z}$ otroki uporablja didaktične igre in igre s pravili. Čeprav so študentje izkazali pričakovano vlogo v otroški igri, kar je pozitivno vplivalo na vzgojno delo in vsesplošno dobro počutje otrok, nekateri pri tem niso bili prepričljivi. Tako se nam zastavlja vprašanje, kako izboljšati pridobivanje kompetenc za igro pri študentih predšolske vzgoje.

Ključne besede: vloge, študentje predšolske vzgoje, kompetence za igro 


\section{Introduction}

Play is a complex human activity with a long and detailed history of research dating back to the beginnings of preschool pedagogy and developmental psychology (Bodrova, 2013; Kamenov, 2006; San Chee, 2014; Trawick Smith, 2008; Vasta, Haith, \& Miller, 2004). Play is a general term for a large number of activities, and must therefore be understood in a holistic and multidisciplinary way (Bodrova, 2013; Kamenov, 2006; San Chee, 2014; Trawick Smith, 2008). Numerous studies have demonstrated the importance of the culture of play for children's development and learning, as well as the fact that it is impossible to separate children's play, learning and development (NCCA, 2009; Schousboe, 2013). Although there is no universal definition of play, there are a number of theoretical frameworks that describe it with common characteristics.

Play can be described as an enjoyable activity, requiring activity (physical, mental) with materials and people. Play is a freely chosen, voluntary process that is focused on satisfying children's interests and emotional needs (Duran, 2003; Gleave \& Cole-Hamilton, 2012). Due to its ability to dominate other activities during early childhood, play has always been at the heart of various approaches to the institutional education of preschool children.

The importance of play is reflected in the fact that children play for pleasure and thereby satisfy their basic needs, contributing to their physical, social, emotional and cognitive well-being (Goldstein, 2012). For the child, play represents an attempt to overcome the discrepancy between personal abilities and behavioural patterns that are important for successful integration into society. The educational value of the most important play lies in its potential to draw children's attention to specific content and to encourage their active involvement (Bodrova, 2013; Kamenov, 2006; San Chee, 2014; Schousboe, 2013; Trawick Smith, 2008).

\section{Preschool children's play}

Play is a general term for a large number of children's activities that convey a message to the child about his/her development and serve as an autonomous socio-cultural reality (NCCA, 2009). Although it is often difficult to distinguish between various types of play, there is an unambiguous differentiating criterion according to which we can distinguish four broad categories of play: functional play, symbolic play, construction (building) play, and play with rules/didactic play.

Functional play is play that includes repetitive movements with no immediate purpose or goal. The child experiences great satisfaction in having 
mastered the movements (Duran, 2003; Kamenov, 2006).

Symbolic play is play in which the children are transferred to an imaginary situation. Such play takes place on an imaginary plane, often supported by toys that replace real objects, with no rules given in advance. This offers greater freedom in procedures and primacy of the imagination over identifying real situations and actions, in line with the conditions dictated by reality (Duran, 2003; Fiorelli \& Russ, 2012; Kamenov, 2006; Šagud, 2002).

Construction or building play involves designing play in which the child forms material to achieve a specific goal as a result of his/her efforts. The creation can be completely without function and meaning (e.g., mosaic), or with meaning (e.g., houses, roads, etc.). The main characteristic of this play is that, with age, the child moves from a metaphorical to a logical way of thinking (Goldstein, 2012; Kamenov, 2006).

Play with rules is play in which rules can be transferred to the child in a variety of ways, showing him/her how to play a particular game or demonstrating how toys function and suggesting certain rules for dealing with them. Such play is often referred to as didactic play. Didactic play is play with rules given in advance, with the function of regulating the content and flow of the play and the behaviour of the child. In addition to establishing rules, didactic play explicitly or implicitly sets a task, whose function is to boost the child's current capacity, to develop latent forces, and to prepare the child for the next stage of development (Vygotsky, 1978). In addition to general properties of play, play with rules includes activities that promote the integral development (sensory, learning, processing and application of knowledge, speech and creativity) of the child (Kamenov, 2006).

Given the main objective in the present study, of even more importance is the fact that each of these various types of play has specific features that define the role of adults in playing with children (NCCA, 2009; Ridgway \& Quinones, 2012). The roles of preschool teachers in playing with children should therefore vary according to the type of play in which the child is engaged. This flexibility contributes strongly to the child's well-being.

\section{Preschool teacher competences}

Competences represent a dynamic combination of cognitive and metacognitive skills, knowledge and understanding, interpersonal and practical skills, and ethical values (Vizek Vidović, 2008). Sheridan and colleagues (2011) observed three highly intertwined and interdependent dimensions of educators' competences. First, the dimensions of competency knowledge: what and why. The teacher should possess knowledge and have the ability to apply it. In 
addition, the teacher must display a desire to learn and gain new knowledge, as well as a capacity to make changes based on the implementation of new knowledge. Another dimension of competence is to know how, reflecting the ability to lead, to organise and to apply knowledge. The third dimension of competence is interaction, relation and transaction, which involves communication, social relations, care for others and learning ability. Due to the numerous factors influencing competence, it is very difficult to define, and the criteria for defining competences vary from culture to culture. Although this is clearly evident in the explanations of general competence, very few studies deal with the specific competences required for play.

The contemporary approach to institutional education emerges from the fact that everyone learns and develops through their own activity, and that children's activities are central to the process. Therefore, the activity of adults is focused on providing the conditions for the smooth progress of children's activities, through encouraging, directing and initiating the development of the child. Overall, the main objective of different types of institutional work with children is to positively contribute to their well-being, and children's play is central to this aim.

The modern approach to education starts from the child, his/her individual needs, interests and developmental laws. The role of parents and educators is significant to the development of children, and is determined by their own activities in interaction with the environment, as interpreted by the child as an active and organised whole that is influenced by dynamically changing experience (Bašić, 2011; Bodrova, 2013; Schousboe, 2013; Trawick Smith, 2008). Interaction takes place in the specific socio-cultural context of the interpersonal relations developed through communication. It is a unique and creative process in which the child acts, explores, questions, supposes, etc., through play. The role of adults is to provide the most appropriate conditions for the activities of the children; they can support children's play or provide guidance for play (Bodrova, 2013). This presents an excellent example of Vygotsky's zone of proximal development (1978): situations in which children can play independently with a little indirect guidance from an adult.

This leads to the question of the need to develop specific competences of various educators. It is very important to note that the dynamics of changes within academic education follows modern world changes, including changes in the role of preschool teachers (Petrović-Sočo, Slunjski, \& Šagud, 2005; Tatalović Vorkapić, Vlah, \& Vujičić, 2012; Tatalović Vorkapić \& Vujičić, 2013; Vujičić, Tatalović Vorkapić, \& Boneta, 2012). Competences acquired by educators can therefore be used in the preschool institutional context in a quality way. 
A new undergraduate university course of Early Childhood and Preschool Education at the Faculty of Teacher Education in Rijeka, Croatia (http:// www.ufri.uniri.hr/en/study-programmes/early-childhood-and-preschool-education.html) presents a response to the much needed and modified role of the preschool teacher within the modern institutional context, such as the kindergarten. The programme should allow the development of both general and specific competences fostering a high level of tolerance towards differences and promoting equal opportunities for all. Amongst basic skills and knowledge, integrated knowledge and its practical application are a significant part of the competences of the preschool teacher. Current knowledge about the development of competences of educators emphasises the necessity of linking the internal and external context in which the initial training takes place. The internal context includes constructs associated with the human personality (Tatalović Vorkapić, 2012), self-esteem, motivation and beliefs, while external factors include the cultural and social circumstances in which the teacher acquires competence. In this area, an empirically well-supported theoretical framework is provided by social constructivism, which assumes that students, learning actively during their initial education and internship, gradually acquire teaching competence and develop a professional identity (Tatalović Vorkapić, Vujičić, \& Čepić, 2014) based on the integration of personal experience and knowledge of educational science (Vizek Vidović, 2005, 2008).

In addition to other courses, the course that is most relevant to the present research - Language and Communication Integrated Curriculum (Katić, 2012) - is organised in such a way that the child is at the centre of students' work. Therefore, the students' primary task is to become acquainted with the child. Along with other information, they should gather information about children by applying the observation method or by deliberately and systematically observing and recording children's behaviour, their learning styles, interests and strengths. Furthermore, they should note all of the significant environmental factors (physical, social, emotional), as well as the educator's personal and professional working characteristics in the group. The main consideration is the behaviour of the child, especially his/her way of communication (verbal and nonverbal). The collected data are analysed and represent the starting point for planning the necessary conditions (material, social, pedagogical) for educational work with the child. The students' role is focused on work with the child (through acceptance, guidance and monitoring of the child's development using qualitative interpersonal relationship). Taking into account pathways of developing the language competence of children, the students are supposed to plan and act using play as the most natural way of learning the language and 
communication skills of children. It is through this specific task that they develop their play competences, along with other competences, because they learn to understand different types of play within the preschool curriculum and their own involvement in supporting child's play.

\section{Play competences - students' involvement in children's play}

The relationship of the educator in and during play in the institutional context has been addressed in very few studies (Edwards, 2011; Sandberg et al., 2012; Schousboe, 2013; Šagud, 2002; Trawick Smith, 2008). Regardless of the type of play, it is important that adults do not dominate; instead, children, as the main bearers of activities, should choose the type of play and determine its organisation and execution. Furthermore, children should be given an opportunity to display initiative, independence and creativity in their freely chosen play (Kamenov, 2006; Ridgway \& Quinones, 2012; Sandberg et al., 2012). For effective participation in children's play, adults should be oriented towards the child rather than towards the task that lies ahead of them. They should be familiar with the psychology of play and should develop the ability to recognise and understand the needs of children, as well as developing the skills that allow them to build friendly, partnership-based, cooperative relations, where their intervention is limited to proposing, promoting and directing. In other words, even though the present analysis is based on the students' plans for educational work, which assumes their occupation with the task rather than the child, during the semester students have an excellent opportunity to really get to know the children in the kindergarten groups in which they undertake their practice. They are therefore able to focus more on the children than the task itself, which is their main role in their future work. These situations allow the students to influence the children's play in such a way that the children play without interference and assistance, without having their initiatives undermined. The students must demonstrate a great deal of ingenuity, patience and kindness. Various forms of adult behaviour can significantly influence children's play: selecting and arranging the play material (undertaken in collaboration with the children); giving advice to children (when asked by the children, and when the adult judges that it is necessary); expressing empathy in a variety of pleasant and unpleasant situations; encouraging; motivating; providing a role model (when using material, more in the sense of how to use the material rather than what to do with it); assisting in the construction and arrangement of the children's experience; observing and analysing the children's activities, with a focus on the process of playing rather than on the immediate results. In short, adults' involvement in children's play focuses on the different possibilities of 
developing and enriching the children's activities, rather than defining the direction in which the activity develops.

In creating play, the quality of adult-child interaction is very important. Research conducted by Wood and colleagues (1980) found that preschool teachers are rarely involved in play with children, as they believe that their primary role is to provide resources for play (incentives), and that their intervention may inhibit creativity and the children's behaviour. The same authors emphasised that there are four possible roles of adults in play: parallel players (adults do not engage in direct interaction with the child, instead playing simultaneously with the purpose of indicating the use of offered incentives); teammates (adults are equal to the child, thus indirectly suggesting the direction of play with evaluation during play); mentors (adults have a dominant role in what they teach and direct the play); representatives of reality (adults teach, instruct and indicate a more realistic reconstruction of reality play) (Wood, McMahon, \& Craunstoun, 1980). Furthermore, Hodkin (1985) observed the role of the educator in play through universal principles that are independent of the activity type, and consequently distinguished the following roles of the educator: play role, where the educator assesses, judges and evaluates the child's activities, and instructor role, where the educator instructs the child and introduces a problem situation to him/her.

Table 1. Categories of students of preschool education according to their involvement in children's play and their definitions (Šagud, 2002)

\begin{tabular}{ll}
\hline $\begin{array}{l}\text { Categories of students of pre- } \\
\text { school education according to } \\
\text { their involvement in children's play }\end{array}$ & $\begin{array}{l}\text { Definition of categories of students of preschool educa- } \\
\text { tion according to their involvement in children's play }\end{array}$ \\
\hline Preschool teacher as a teammate & $\begin{array}{l}\text { The preschool educator is an actor; he/she is involved in } \\
\text { the common scenario of the play and takes one of the } \\
\text { roles. }\end{array}$ \\
\hline $\begin{array}{ll}\text { Preschool teacher as the one who } \\
\text { elaborates the play }\end{array}$ & $\begin{array}{l}\text { This category includes all responses by preschool } \\
\text { teachers that indirectly influence the development or } \\
\text { enrichment of the children's play, with the educator's } \\
\text { statements providing information regarding the current } \\
\text { scenario of the play, in which the structure of prior } \\
\text { experience extends a theme reminiscent of the play or a } \\
\text { sequence of actions. }\end{array}$ \\
\hline $\begin{array}{l}\text { Preschool teacher as the one who } \\
\text { elaborates on the child's idea }\end{array}$ & $\begin{array}{l}\text { The testimony of the child is the starting point for } \\
\text { developing themes, enriching the play with new roles or } \\
\text { actions. }\end{array}$ \\
\hline $\begin{array}{l}\text { Preschool teacher as the one who } \\
\text { indicates roles or stakeholders }\end{array}$ & $\begin{array}{l}\text { This category includes all statements with which pre- } \\
\text { school teachers define a role or nominate children to play } \\
\text { a role. }\end{array}$ \\
\hline
\end{tabular}




\begin{tabular}{|c|c|}
\hline $\begin{array}{l}\text { Preschool teacher as the one who } \\
\text { provides information }\end{array}$ & $\begin{array}{l}\text { These are verbal statements by preschool teachers that } \\
\text { are not directly linked to the current theme of the play, } \\
\text { but respond to the children's questions or express the } \\
\text { intention of the preschool teachers. }\end{array}$ \\
\hline $\begin{array}{l}\text { Preschool teacher as the one who } \\
\text { asks questions }\end{array}$ & $\begin{array}{l}\text { This category includes all of the statements presented by } \\
\text { teachers in the form of questions and their differentiation } \\
\text { according to the intentions. }\end{array}$ \\
\hline $\begin{array}{l}\text { Preschool teacher as the one who } \\
\text { demonstrates the procedure and } \\
\text { instructions }\end{array}$ & $\begin{array}{l}\text { These are circumstances where the preschool teacher } \\
\text { demonstrates in order to instruct the child as to the ap- } \\
\text { propriate representation of a specific action. }\end{array}$ \\
\hline $\begin{array}{l}\text { Preschool teacher as the one who } \\
\text { makes rules }\end{array}$ & $\begin{array}{l}\text { The preschool teacher tries to implement rules and the } \\
\text { established norms, and the play arises from real social } \\
\text { relations that are represented and modified within it. }\end{array}$ \\
\hline $\begin{array}{l}\text { Preschool teacher as the one who } \\
\text { adjusts inaccurate comprehension }\end{array}$ & $\begin{array}{l}\text { The preschool teacher corrects the child's inaccurate or } \\
\text { incomplete knowledge. }\end{array}$ \\
\hline $\begin{array}{l}\text { Preschool teacher as the one who } \\
\text { evaluates the child's activity }\end{array}$ & $\begin{array}{l}\text { The preschool teacher provides the idea and comments } \\
\text { on or "scores" the child's play, thus encouraging the child. }\end{array}$ \\
\hline $\begin{array}{l}\text { Preschool teacher as the one who } \\
\text { commends the child }\end{array}$ & $\begin{array}{l}\text { The preschool teacher gives short, typical statements, } \\
\text { providing feedback on the child's actions, without a } \\
\text { broader explanation. }\end{array}$ \\
\hline $\begin{array}{l}\text { Preschool teacher as the one who } \\
\text { provides new material }\end{array}$ & $\begin{array}{l}\text { During the play, the preschool teacher provides specific } \\
\text { material for its enrichment and extension. }\end{array}$ \\
\hline $\begin{array}{l}\text { Preschool teacher as the one who } \\
\text { reorganises the space }\end{array}$ & $\begin{array}{l}\text { The preschool teacher suggests a new organisation of the } \\
\text { space in order to play freely. }\end{array}$ \\
\hline $\begin{array}{l}\text { Preschool teacher as the one who } \\
\text { includes the child }\end{array}$ & $\begin{array}{l}\text { The preschool teacher seeks to involve a child watching } \\
\text { the play, accepting the wishes of the child and the group. }\end{array}$ \\
\hline $\begin{array}{l}\text { Preschool teacher as the one who } \\
\text { encourages independence }\end{array}$ & $\begin{array}{l}\text { The preschool teacher encourages the child to resolve } \\
\text { a problem related to the play (action, role, organisation } \\
\text { of the space, resources, etc.), or to resolve a conflict } \\
\text { between teammates. }\end{array}$ \\
\hline $\begin{array}{l}\text { Preschool teacher as the one who } \\
\text { repeats the child's expression }\end{array}$ & $\begin{array}{l}\text { The preschool teacher repeats the child's statement in an } \\
\text { effort to give the child an opportunity to start or continue } \\
\text { to communicate, or as a way of showing interest in the } \\
\text { child's activity. }\end{array}$ \\
\hline $\begin{array}{l}\text { Preschool teacher as the one who } \\
\text { determines the theme of the play }\end{array}$ & $\begin{array}{l}\text { The preschool teacher directly and explicitly defines the } \\
\text { theme of the play, without joint agreement or feedback } \\
\text { regarding the child's (children's) interests and prefer- } \\
\text { ences. }\end{array}$ \\
\hline $\begin{array}{l}\text { Preschool teacher as the one who } \\
\text { determines the child's action }\end{array}$ & $\begin{array}{l}\text { The preschool teacher directly imposes a gaming model } \\
\text { and pattern within which the play role or action should } \\
\text { unfold. }\end{array}$ \\
\hline $\begin{array}{l}\text { Preschool teacher as the one who } \\
\text { performs the task instead of the } \\
\text { child }\end{array}$ & $\begin{array}{l}\text { The preschool teacher does not encourage or direct the } \\
\text { child to independently find a way to solve a particular } \\
\text { problem, but performs the task without any explanation } \\
\text { or understanding on the part of the child, such as toy } \\
\text { stores, governing the play room and so on. }\end{array}$ \\
\hline $\begin{array}{l}\text { Preschool teacher as the one who } \\
\text { criticises }\end{array}$ & $\begin{array}{l}\text { The preschool teacher negatively assesses the child's } \\
\text { behaviour. }\end{array}$ \\
\hline $\begin{array}{l}\text { Preschool teacher as the one who } \\
\text { does not agree with the child's idea }\end{array}$ & $\begin{array}{l}\text { The preschool teacher rejects the child's idea as bad and } \\
\text { unacceptable. }\end{array}$ \\
\hline $\begin{array}{l}\text { Preschool teacher as the one who } \\
\text { resolves conflicts }\end{array}$ & $\begin{array}{l}\text { The preschool teacher arbitrates in a conflict between the } \\
\text { children, seeking the culprit. }\end{array}$ \\
\hline $\begin{array}{l}\text { Preschool teacher as the one who } \\
\text { demands order and discipline }\end{array}$ & $\begin{array}{l}\text { The preschool teacher demands order and quiet, and his/ } \\
\text { her request is not derived from the content of the play. }\end{array}$ \\
\hline
\end{tabular}


Finally, the National Council for Curriculum and Assessment (NCCA, 2009) emphasises that enriching and extending learning through play can be done by following three major steps: a) planning for play; b) supporting play; and c) reviewing play.

Of all of the required competences that should be highly developed in future preschool teachers, play competences are the most important. The categories of involvement during children's play (Šagud, 2002), as an instrument relating to the categories of educators' behaviour in symbolic play, have been used as a category tool in the present study. The main argument for their application lies in their applicability to other types of play: functional, with rules of play, building and construction play. These involvement categories are presented in detail in Table 1. As can be seen, they present various educators' behaviours that can be observed while children play. Most of these educators' behaviours do not involve the shared play of children and educator, but rather concern solitary children's play or play with peers. The broad nature of these categories facilitates a detailed understanding and analysis of the development of play competences amongst students of preschool education.

Taking all of these factors into account, it is very important to build quality competences of students of preschool education in creating skilful behaviour that encourages children to play without obstructing their play, thus contributing directly to their well-being. Given that this is not easy to achieve, the aim of the present study was to analyse the involvement categories of students of preschool education in the play of preschool children, as presented in the students' written plans during their study. Within this general aim, two research problems were established. First, the type of play chosen by the students as a tool for educational work with children should be determined and analysed. Second, the students' involvement in children's play should be determined and analysed. Both tasks will be examined through qualitative analysis and descriptive statistics. In view of the age of the children (two- and threeyear-olds), it was expected that the students would primarily choose play with rules and didactic play, and that they would display all of the behaviours that encourage children to play without obstructing play.

\section{Method}

\section{Subjects}

A total of 36 students of preschool education participated in the study ( 35 females and 1 male), with an average age of 21 years. The subjects were students enrolled in the third year of the undergraduate study programme Early 
and Preschool Care and Education at the Faculty of Teacher Education, University of Rijeka. The students were told that the aim of the study was to explore their involvement behaviours during children's play. Their participation in the study was completely voluntary and anonymous, and they were promised to be provided with feedback on the research results.

\section{Instrument and procedure}

The students had to write a plan for conducting educational work with children aged 2-3 years, within the framework of the subject course LanguageCommunications Curriculum in their third academic year. The purpose of their plans was to obtain the following information: after closely observing the children, the students should state: a) what type of play they intend to use in their interaction with the children in shared play; and, b) what kind of involvement they intend to have while the children play (their behaviour should be explained by the children's behaviour and needs). Their written plans therefore provided material for the qualitative analyses. The students worked on their written plans in groups of three (twelve groups in total), during the entire sixth semester (with a duration of three months). Afterwards, their teacher collected all twelve written plans and removed the names of the students, so that the written material could be given to the two independent researchers who would undertake the qualitative analysis. The researchers aimed to accomplish several tasks during the qualitative analysis: to read all of the plans carefully, to collect all of the suggested forms of play, to identify all of the involvement behaviours of the students during their practice in the kindergarten, and to place these behaviours in the correct involvement category. Both of the researchers had the same definitions of behavioural categories describing the students' involvement during the children's play, as described above (Table 1). The researchers also counted the frequency of involvement type for each category. The final version of the categories and the frequency of the answers in each category was the result of their estimation concurrence.

\section{Results and discussion}

Using the qualitative methodology, the analysis first identified the type of play primarily used by the students in their educational work with 2- and 3 -year-old children. The main type of involvements manifested in their interaction with the children were then determined and analysed. Table 2 shows all of the types of play used by the students in their educational work with the children and the shared play, as well as their frequency of occurrence.

All 12 groups of students chose didactic play as one of the activities 
aimed at providing the conditions for the linguistic communication development of the children in the educational group. The findings show that the students applied 40 types of didactic play in total. During their independent work with the children, as many as seven different types of didactic play were applied by the first group of students. Similarly, the fourth and sixth groups of students also used five and six different types of didactic play, respectively. All of the other students groups used four or fewer types of didactic play during their practice in kindergarten. The total of 40 planned and implemented types of play indicates that the students recognised play as the key activity encouraging the development of language-communication skills amongst children (Flynn, 2011; Pavličević-Franić, 2005).

Table 2. Frequencies (per group and total) of play chosen by the students

\begin{tabular}{|c|c|c|c|c|c|c|c|c|c|c|c|c|c|c|c|}
\hline \multirow{2}{*}{ 을 } & \multirow[b]{2}{*}{ Play } & \multicolumn{12}{|c|}{ Frequency of roles for each student group ( $N=12$ groups) } & \multirow{2}{*}{ 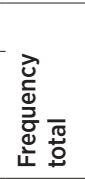 } & \multirow[b]{2}{*}{ 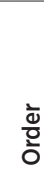 } \\
\hline & & - & $=$ & $\equiv$ & $\geq$ & $>$ & $>$ & $\bar{\Sigma}$ & $\overline{\bar{\Sigma}}$ & $\underline{x}$ & $\times$ & $\bar{x}$ & $\overline{\bar{x}}$ & & \\
\hline 12 & Didactic play & 7 & 2 & 3 & 5 & 4 & 1 & 6 & 1 & 4 & 2 & 3 & 2 & 40 & 1 \\
\hline 8 & Play with rules & & 1 & 1 & 3 & & 2 & 2 & 1 & & 3 & 1 & & 14 & 2 \\
\hline 3 & Symbolic play & & & & & & & & 1 & & & 1 & 1 & 3 & 3 \\
\hline 1 & Functional play & & & & & & & & 1 & & & & & 1 & 4 \\
\hline 1 & Constructive play & & & & & & & & & & & 1 & & 1 & 5 \\
\hline Total & & 7 & 3 & 4 & 8 & 4 & 3 & 8 & 4 & 4 & 5 & 6 & 3 & 59 & \\
\hline
\end{tabular}

Eight groups of students chose play with rules, realising a total of 14 such types of play. This kind of play involves rules as the basis for the development of play. All players are obliged to adhere to the rules, and this is governed by a type of code of play. This is extremely important for the moral aspect of development, as the ability to accept and follow rules that come from the environment is learned through this type of play (Duran, 2003). At the same time, children have an opportunity to experience the process of socialisation and the regulation of social relations within a group. The rules can vary according to the content, the resources for play, and the aspects of development addressed. Moreover, explaining rules to the children and discussing them has a strong impact on the development of the language-communication skills of children (Vasta, Haith, \& Miller, 2004).

It is interesting to note that only three student groups used symbolic play in their work with children. Finally, the eighth group of students used only one functional play, while the twelfth group used only one constructive play or 
play of building and construction. All of these types of play have their own educational outcome and specific effects on certain aspects of child development.

One possible explanation for the most frequent use of didactic play is the key role of rules in play with rules and didactic play. The function of rules is to regulate the content and flow of the play, and the behaviour of the children. The content of the play can be diverse and varied, as evidenced by the names that the students used. In terms of the children's behaviour, the rules prohibit, permit and prescribe what is done. Besides the rules, in play with rules and didactic play as a special type of play with rules there is an explicit or implicit set task. For the child, it presents a situation in which he/she has to solve a problem in a creative way, according to his/her cognitive level and using his/her previous experience, voluntary effort and ability to communicate with other children and adults, as well as his/her ability of self-control. The effort invested in the child's problem solving is the main lever of the development of perception, thought and speech, as well as the ability to use available knowledge. In this context, play with rules and didactic play have the function of developing the current and potential capabilities and abilities of the child, thus preparing $\mathrm{him} /$ her for the next developmental stage, which corresponds to the theory of social constructivism (Kamenov, 2006; Gopnik et al., 2001). Play with rules has a strong educational value, and it should be undertaken every day and connected with other activities. In this type of play - as opposed to other types, mostly arranged by adults - the level of requirements and efforts is determined in order to focus on certain areas of development. Although the educator has a guiding role, it is important that the children have an opportunity to choose the play, establish the way of playing, change the rules, and choose a partner as well as a leader in the play.

Considering the age of the children, this finding is as expected. All of the groups of students used the didactic type of play, and this type of play was the most frequent, as can be seen in Table 2. Amongst didactic types of play, the students mainly used various puzzles appropriate to the age of the children ("Rabbit Grey", "Magic Forest", "Serpent Sun", "Colourful Basket", "Dog Rony", "Cat Mima", "Horse Black Beauties", etc.), or other types of didactic play: "Find a pair", "Where do I belong?", "Recognise a sign!".

As can be also seen in Table 2, 14 types of play with rules were used in eight groups of students. Some of these types of play were: "Ivan eats vegetables", "Come to a big and small friend", "Find a place for a bug", "Cube swivels", "Mum and baby".

Symbolic play was applied on only three occasions, one of them being "Cooking lunch for guests". Only one group used functional play ("Orchard") 
and one used constructive play ("Building homes for hedgehogs"). The names of the play indicate an appreciation of the children's interest in securing the conditions in which to play. Regardless of the type of play chosen in accordance with the objectives, it is important to take into account the ability, needs and desires of the children, and to give preference to topics related to their experiences, as confirmed by the students in their choice of title of the play type (WilcoxHerzog, 2004).

The categories of student involvement in the children's play and the frequency of the categories by groups and in total are presented in Table 3. Given the described behaviour of the students' interaction with the children, and without considering the number of plays offered, all of the groups of students elaborated the play, demonstrated the procedure and instructions, provided information, made rules, asked questions and acted as teammates. Furthermore, all of the categories, except involvement of the preschool teacher as a teammate, had a higher frequency in all twelve groups. The most frequently executed category was that of the preschool teacher as the one who elaborates the play. This was followed by the one who demonstrates the procedure and instructions, the one who provides information, the one who makes rules, and the one who asks questions. The frequency of responses is in accordance with the type of play chosen, such as play with the rules or didactic play, whose main characteristic is that it is subordinate to a specific training-educational task arising from the introduction of child development.

Table 3. Frequencies (per group and total) of categories of preschool teachers' involvement in children's play

\begin{tabular}{|c|c|c|c|c|c|c|c|c|c|c|c|c|c|c|c|}
\hline \multirow[b]{2}{*}{ 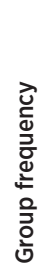 } & \multirow{2}{*}{$\begin{array}{l}\text { Categories of preschool } \\
\text { teachers' involvement in } \\
\text { children's play: } \\
\text { Preschool teacher as the } \\
\text { one who... }\end{array}$} & \multicolumn{12}{|c|}{$\begin{array}{l}\text { Frequency of categories for each student group } \\
\text { ( } N=12 \text { groups) }\end{array}$} & \multirow[b]{2}{*}{ 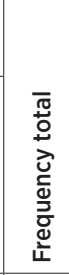 } & \multirow[b]{2}{*}{$\frac{\grave{\partial}}{\mathrm{c}}$} \\
\hline & & - & $=$ & $\equiv$ & $\geq$ & $>$ & $>$ & $\bar{\Sigma}$ & $\overline{\bar{\nu}}$ & $\underline{x}$ & $x$ & $\bar{x}$ & $\overline{\bar{x}}$ & & \\
\hline 12 & ...elaborates the play & 4 & 2 & 5 & 5 & 3 & 3 & 3 & 3 & 3 & 3 & 6 & 4 & 44 & 1 \\
\hline 12 & $\begin{array}{l}\text {...demonstrates the proce- } \\
\text { dure and instructions }\end{array}$ & 4 & 3 & 5 & 5 & 3 & 3 & 3 & 2 & 3 & 3 & 5 & 4 & 43 & 2 \\
\hline 12 & ...provides information & 6 & 1 & 5 & 5 & 3 & 3 & 3 & 3 & 3 & 3 & 2 & 4 & 41 & 4 \\
\hline 12 & ...makes the rules & 2 & 3 & 5 & 5 & 2 & 3 & 3 & 1 & 3 & 2 & 6 & 4 & 39 & 5 \\
\hline 12 & ...asks questions & 2 & 1 & 4 & 5 & 3 & 1 & 1 & 3 & 3 & 3 & 6 & 4 & 36 & 6 \\
\hline 12 & ...is a teammate & 3 & 1 & 3 & 3 & 2 & 1 & 3 & 2 & 2 & 3 & 5 & 3 & 31 & 9 \\
\hline 11 & $\begin{array}{l}\text {...encourages indepen- } \\
\text { dence }\end{array}$ & 6 & 4 & 4 & 5 & 1 & 3 & 3 & 3 & 3 & 0 & 6 & 4 & 42 & 3 \\
\hline
\end{tabular}




\begin{tabular}{|c|c|c|c|c|c|c|c|c|c|c|c|c|c|c|c|}
\hline 11 & ...provides new material & 3 & 4 & 3 & 4 & 3 & 1 & 3 & 3 & 3 & 3 & 0 & 4 & 34 & 7 \\
\hline 11 & ...reorganises the space & 1 & 4 & 2 & 1 & 2 & 1 & 3 & 3 & 3 & 3 & 0 & 4 & 27 & 10 \\
\hline 10 & $\begin{array}{l}\text {...elaborates on the child's } \\
\text { idea }\end{array}$ & 0 & 0 & 2 & 4 & 2 & 3 & 3 & 3 & 3 & 3 & 6 & 4 & 33 & 8 \\
\hline 10 & $\begin{array}{l}\text {...indicates the role or } \\
\text { stakeholders }\end{array}$ & 1 & 0 & 4 & 3 & 2 & 2 & 3 & 2 & 2 & 2 & 0 & 1 & 22 & 12 \\
\hline 9 & $\begin{array}{l}\text {...determines the child's } \\
\text { action }\end{array}$ & 2 & 0 & 4 & 4 & 2 & 3 & 0 & 1 & 0 & 2 & 3 & 2 & 23 & 11 \\
\hline 8 & $\begin{array}{l}\text {...determines the theme of } \\
\text { the play }\end{array}$ & 3 & 2 & 0 & 0 & 3 & 3 & 0 & 1 & 0 & 2 & 3 & 2 & 19 & 13 \\
\hline 5 & $\begin{array}{l}\text {...repeats the child's } \\
\text { expression }\end{array}$ & 0 & 0 & 0 & 2 & 0 & 0 & 1 & 0 & 1 & 3 & 4 & 0 & 11 & 14 \\
\hline 5 & $\begin{array}{l}\text {...performs the task } \\
\text { instead of the child }\end{array}$ & 1 & 0 & 1 & 0 & 0 & 0 & 2 & 0 & 1 & 1 & 0 & 0 & 6 & 16 \\
\hline 3 & ...includes the child & 0 & 1 & 0 & 0 & 2 & 0 & 0 & 0 & 0 & 0 & 6 & 0 & 9 & 15 \\
\hline 3 & ...commends the child & 0 & 0 & 1 & 1 & 0 & 0 & 0 & 0 & 0 & 0 & 1 & 0 & 3 & 18 \\
\hline 2 & $\begin{array}{l}\text {...adjusts inaccurate com- } \\
\text { prehensions }\end{array}$ & 0 & 0 & 1 & 0 & 0 & 0 & 0 & 0 & 0 & 0 & 4 & 0 & 5 & 17 \\
\hline 2 & $\begin{array}{l}\text {...evaluates the child's } \\
\text { activity }\end{array}$ & 0 & 0 & 2 & 1 & 0 & 0 & 0 & 0 & 0 & 0 & 0 & 0 & 3 & 19 \\
\hline 2 & $\begin{array}{l}\text {...demands order and } \\
\text { discipline }\end{array}$ & 0 & 0 & 0 & 0 & 0 & 0 & 1 & 1 & 0 & 0 & 0 & 0 & 2 & 20 \\
\hline 0 & ... criticises & 0 & 0 & 0 & 0 & 0 & 0 & 0 & 0 & 0 & 0 & 0 & 0 & 0 & 21 \\
\hline 0 & $\begin{array}{l}\text {...does not agree with the } \\
\text { child's idea }\end{array}$ & 0 & 0 & 0 & 0 & 0 & 0 & 0 & 0 & 0 & 0 & 0 & 0 & 0 & 22 \\
\hline 0 & ...resolves conflicts & 0 & 0 & 0 & 0 & 0 & 0 & 0 & 0 & 0 & 0 & 0 & 0 & 0 & 23 \\
\hline Total & & 38 & 26 & 51 & 53 & 33 & 30 & 35 & 31 & 33 & 36 & 63 & 44 & 473 & \\
\hline
\end{tabular}

In this case, the focus is on the development of the child's language and communication skills. The findings indicate the role of the students in that ten groups encouraged the independence of the children, which is also in line with the above types of play that include the expression of the child's opinion, as speech is, of course, a means of expressing opinion (Stančić \& Ljubešić, 1994). Although the role of the preschool teacher as a teammate is mentioned in all twelve groups, it is in ninth place according to frequency in the written plans. This means that the frequency of using these involvement categories is not as high as expected (NCCA, 2009).

Eleven groups encouraged independence, gave new materials and reorganised the space, while ten groups elaborated on the child's idea and indicated the role or stakeholders. Although the type of involvement within which students encouraged the child's independence was mentioned by eleven groups, it was in third place in terms of frequency. This finding implies that this role is important to students and has a strong presence in their interaction with preschoolers. This role was followed by roles in which students provided new materials and reorganised the space in order to enrich the children's play. Although 
elaborating on the child's idea was mentioned in two groups of students, its frequency ranking was eight, after asking questions and providing material for the children's play. Ten groups also chose roles in which the students indicated the role or stakeholder, but the frequency of the strategy was ten times less than other types of involvement.

Nine groups determined the child's action, eight groups determined the theme of the play, and five groups repeated the child's expression and performed the task instead of the child. All of these roles demonstrated appropriate frequency within the groups, except for the last one, which was mentioned in five groups only six times (just over one mention per group). Three groups reported types of involvement that included commending the child's behaviour. Roles in which the adult commends the child's behaviour are very important for the child's learning, and it was therefore expected that such roles would be manifested more often; however, the students did not demonstrate this type of behaviour very often in the context of children's play. This particular finding is very important and is worth emphasising, as it suggests that students of preschool education should be encouraged to give more commendations to preschool children. Commending a child has a strong reinforcement effect, and represents a major verbal tool for creating and encouraging desirable and positive behaviours in children (Seligman, 1996; Vasta, Haith, \& Miller, 2004), directly contributing to the children's well-being (Goldstein, 2012). These types of reinforcements should therefore be used more often in adult-child interaction.

Two groups adjusted inaccurate comprehensions, evaluated the child's activity and demanded order and discipline. None of the groups criticised the children's behaviour, showed disagreement with the child's idea or resolved conflict. This finding is in line with the expected behaviour of students in children's play.

\section{Conclusion}

In the context of preschool education, the importance of play is strongly highlighted (Goldstein, 2012). Although theories of children's learning have changed throughout history, in most theories, play is viewed as an act of learning or as an object of learning (i.e., play is meaningful in itself and is therefore of value for the children's well-being) (Pramling Samuelsson \& Asplund-Carlsson, 2003).

The present study reveals that students of preschool education primarily use didactic play with children and demonstrate those types of involvement that are consistent with their future play competences. Although, in children's 
play, students show the expected behaviour that is positively related to their educational work, some of the expected behaviours are not present, such as commending the child. This finding provides very important information related to the question of which competences should be given emphasis, not only in the course in question, but in the entire study programme of preschool teachers. In addition, students use symbolic play significantly less than didactic play, which could imply that they feel more competent within clearly structured shared play (applying didactic play based on rules). Symbolic play is very important for the development of children's symbolic thinking and for their cognitive development overall, and should therefore be used very often. On the other hand, the role of adults within symbolic play requires much more flexibility and management in a less structured form, which could be why this kind of play is not used more frequently. The development of these specific play competencies in students of preschool education could be one of the future tasks in study programme modifications.

The acquisition of competence is a multidimensional process that requires broader consideration. A more complete insight into play competences would require an analysis of all of the situations in which students have an opportunity to participate in educational work with children. Therefore, the expert and scientific value of the present research paper can be recognised in the following elements:

- the study compensates in part for the small amount of research on adults' involvement in children's play;

- the initial training of students of preschool education needs to be aligned with the modern theory and practice of preschool education;

- $\quad$ play competencies of students of preschool education should be clearly articulated.

Outcomes of the Faculty of Education include students' readiness for transformation through acquiring theoretical knowledge, as well as an ability to ensure conditions for developing the child's potential that are aligned to the child's needs, abilities and interests. It is therefore important to change the behavioural patterns of students' involvement in children's play, transforming them from listeners and observers to active partners in personal vocational training (Budić et al., 2008; Ridgway \& Quinones, 2012), capable of providing an adequate type of support in enhancing children's play, and consequently their well-being (NCCA, 2009). 


\section{References}

Bašić, S. (2011). Nova slika djeteta u pedagogiji djetinjstva. In D. Maleš (Ed.), Nove paradigme ranog odgoja. Zagreb: Filozofski fakultet Sveučilišta u Zagrebu, Zavod za pedagogiju.

Bodrova, E. (2013). Play and Self-Regulation. Lessons from Vygotsky. American Journal of Play, 6(1), 111-123.

Budić, S., Gajić, O., Segedinac, M., Miljanović, T., \& Španović, S. (2008). Didaktičko - metodički aspekti studentske prakse u partnerskim relacijama fakultetea $i$ škola. Novi Sad: Filozofski fakultet, Odsjek za pedagogiju.

Duran, M. (2003). Dijete i igra (4. Izdanje). Jastrebarsko: Naklada Slap.

Edwards, S., \& Cutter-Mackenzie, A. (2011). Environmentalising early childhood education curriculum through pedagogies of play. Australasian Journal of Early Childhood, 36, 51-59.

Faculty of Teacher Education, University of Rijeka. (2010). Early childhood and preschool educationCourse program. Retrieved 11 September 2013 from http://www.ufri.uniri.hr/en/study-programmes/ early-childhood-and-preschool-education.html

Fiorelli, J. A., \& Russ, S. W. (2012). Pretend Play, Coping, and Subjective Well-Being in Children. American Journal of Play, 5(1), 81-103.

Flynn, K. S. (2011). Developing Children's Oral Language Skills through Dialogic Reading Guidelines for Implementation. Teaching Exceptional Children, 44(2), 8-16.

Gleave, J., \& Cole Hamilton, I. (2012). A world without play: A literature review on the effects of a lack of play on children's lives. London: Play England. Retrieved 1 March 2013 from www.btha.co.uk Goldstein, J. (2012). Play in children's development, health and well-being. Brussels: Toy Industries of Europe (TIE).

Gopnik, A., Meltzoff, A. N., \& Kuhl, P. K. (2001). The Scientist in the Crib: What Early learning Tells Us About the Mind. New York, NY: Perennial, An Imprint of Harper Collins Publishers.

Hodkin, R. A. (1985). Playing and exploring: Educational trough the discovery of order. London, New York: Methuen.

Kamenov, E. (2006). Dečja igra: vaspitanje i obrazovanje kroz igru. Beograd: Zavod za udžbenike. Katić, V. (2012). Syllabus of Language-Communications Curriculum. Rijeka: Faculty of Teacher Education, University of Rijeka.

NCCA. (2009). AISTEAR: The early childhood curriculum framework - Guidelines for good practice.

Dublin: National Council for Curriculum and Assessment. Retrieved 1 March 2013 from www.ncca.ie Pavličević-Franić, D. (2005). Komunikacijom do gramatike. Zagreb: Alfa.

Petrović-Sočo, B., Slunjski, E., \& Šagud, M. (2005). A new learning paradigm - A new roles of preschool teachers in the educational process. Zbornik Učiteljske akademije u Zagrebu, 7(2), 329-340. Pramling Samuelsson, I., \& Asplund-Carlsson, M. (2003). Detlärandebarnet. Påväg mot en teori [The learning child-Toward a theory]. Stockholm, Sweden: Liber.

Ridgway, A., \& Quinones, G. (2012). How do Early Childhood Students Conceptualize Play-Based Curriculum?. Australian Journal of Teacher Education, 37(12), 45-56. 
San Chee, J. (2014). Intentional learning with educational games: A Deweyan reconstruction.

Australian Journal of Education, 58(1), 59-73.

Sandberg, A., Lillvist, A., Sheridan, S., \& Williams, P. (2012). Play competence as a window to preschool teachers' competence. International Journal of Play, 1(2), 184-196.

Schousboe, I., \& Winter Lindqvist, D. (2013). Children's Play and development, Cultural - Historical Perspectives. New York, London: Springer Dordrecht Heidelberg.

Seligman, M. E. P. (1996). The Optimistic Child: Proven Program to Safeguard Children from Depression \& Build Lifelong Resilience. New York, NY: Houghton Mifflin.

Sheridan, S., Williams, P., Sandberg, A., \& Vuorinen, T. (2011). Preschool teaching in Sweden - A profession in change. Educational Research, 53(4), 415-437.

Stančić, V., \& Ljubešić, M. (1994). Jezik, govor, spoznaja. Zagreb: Hrvatska Sveučilišna naklada. Šagud, M. (2002). Odgajatelj u dječjoj igri. Zagreb: Školske novine.

Tatalović Vorkapić, S. (2012). The significance of preschool teacher's personality in early childhood education: Analysis of Eysenck's and Big Five Dimensions of personality. International Journal of Psychology and Behavioral Sciences, 2(2), 28-37.

Tatalović Vorkapić, S., \& Vujičić, L. (2013). Do we need Positive Psychology in Croatian kindergartens? The implementation possibilities evaluated by preschool teachers. Early Years: An International Journal of Research and Development, 33(1), 33-44.

Tatalović Vorkapić, S., Vlah, N., \& Vujičić, L. (2012). Osnaživanje uloge budućih odgajatelja u očuvanju mentalnog zdravlja predškolske djece: Promjene studijskog programa. Život i škola, 28(2), 130-144.

Tatalović Vorkapić, S., Vujičić, L., \& Čepić, R. (2014). Pre-school Teacher Identity. In P. Breen (Ed.), Cases on Teacher Identity, Diversity, and Cognition in Higher Education (pp. 22-60), A volume in the Advances in Higher Education and professional Development (AHEPD) Book Series, IGI Global. doi: 10.4018/978-1-4666-5990-2

Trawick-Smith, J. (2008). Teacher-Child Play Interactions in Preschool: An Empirical test of Vygotsky's Theory. Retrieved 1 March 2014 from http://www.easternct.edu/cece/pdf/TrawickSmith\%2oteacher child\%2oplay\%2ointeractions.pdf

Vasta, R., Haith, M. M., \& Miller, S. A. (2004). Child psychology (4 ${ }^{\text {th }}$ ed.). New York, NY: Wiley. Vizek Vidović, V. (2005). Profesionalni razvoj učitelja tijekom inicijalnog obrazovanja i pripravništva. Zagreb: Institut za društvena istraživanja. Retrieved 1 March 2013 from http://zprojekti.mzos.hr/ public/c2prikaz_det.asp?cid=1\&psid=29\&offset $=20 \& \mathrm{ID}=1172$

Vizek Vidović, V. (2008). Ishodi učenja u obrazovanju učitelja i nastavnika - konceptualni okvir. Zagreb: Projekt nacionalne zaklade za znanost. Retrieved 1 March 2013 from http://domus.srce.hr/ iuoun

Vujičić, L., Tatalović Vorkapić, S., \& Boneta, Ž. (2012). Istraživanje odgojno-obrazovne prakse: Dominantna strategija profesionalnog razvoja odgajatelja. In I. Pehlić, E. Vejo, \& A. Hasanagić (Eds.), Suvremeni tokovi u ranom odgoju, Znanstvena monografija (pp. 345-363). Zenica: Islamski Pedagoški fakultet Sveučilišta u Zenici. 
Wilcox-Herzog, A., \& Ward, S. L. (2004). Measuring Teachers' Perceived Interactions with Children: A Tool for Assessing Beliefs and Intentions. Early Childhood Research \& Practice, 6(2). Retrieved 1 March 2013 from http://ecrp.uiuc.edu/v6n2/herzog.html Wood, D., McMahon, L., \& Craunstoun, Y. (1980). Working with under Fives. Oxford preschool research project. London: Grant McIntyre.

Vygotsky, L. S. (1978). Mind in society. Cambridge, MA: Harvard University Press.

\section{Biographical note}

Sanja Tatalović Vorkapić, Ph.D., Assistant Professor and teaches students at Faculty of Teacher Education, University of Rijeka, Croatia in: Developmental psychology, Psychology of early learning and teaching, General psychology, Emotional intelligence, Developmental psychopathology, Methodology of quantitative research, Positive psychology. Her contemporary research interests include biological basis of personality, personality of (pre)school teachers and child personality in education, contemporary issues in developmental psychopathology and methodology of quantitative research, positive psychology and its relationship with other fields, and also study programs development for (pre)school teachers. She has published numerous psychology related articles and has been actively involved within various interdisciplinary research projects.

VeSnA KATIĆ, is a Higher Lecturer and teaches students at the Faculty of Teacher Education, University of Rijeka, Croatia in: Orientation Practicum, Language-Communication integrated Curriculum, Reflective practice, Development and collaborative research competencies, Family pedagogy, Preschool, Alternative concepts in preschool education. Her contemporary research interests mostly include the field of Early and Pre-school Education. She is also a trainer of the Open University "Step by step" in Croatia on the application of quality child centred methodology and application of the ISSA Pedagogical Standards. She has published several pedagogy related articles and has been actively involved with several interdisciplinary research projects. 